\title{
Author Index Volume 22 (2002)
}

The issue number is given in front of the page numbers.

Anderson, W.L., CODATA work in archiving scientific data

$(2,3) \quad 63-67$

Dong, E. and B. Wang, Copyright of electronic publishing

(1) $27-31$

Elliott, R., Archives of electronic material in science: A view from ICSU

$(2,3) \quad 69-71$

Hauer, M. and W. Simedy, intelligentCAPTURE 1.0 adds tables of content to library catalogues and improves retrieval

(4) $145-149$

Heterick, B., Applying the lessons learned from retrospective archiving to the digital archiving conundrum

Hodge, G.M., Digital preservation: Overview of current developments

Hunter, K., STM members and digital archiving

$(2,3) 113-120$

$(2,3) \quad 73-82$

$(2,3) \quad 83-88$

Lin, B., see Preston, C.

(1) $9-17$

Mahon, B., Summary report

Mahon, B. and E. Siegel, Preface

Malinconico, S.M., Digital preservation technologies and hybrid libraries

Molholm, K.N., Opening remarks

Morris, S., The preservation problem: Collaborative approaches

$(2,3) \quad 51-56$

$(2,3) \quad 49-50$

(4) $159-174$

$(2,3) \quad 57-61$

$(2,3) 127-132$

Paskin, N., Digital object identifiers

Preston, C. and B. Lin, Database technology in digital libraries

$(2,3) \quad 97-112$

(1) $9-17$

Reidy, D.V., The electronic Icarus: some problems and some solutions in digitisation

(4) $151-157$

Scott, B., The pedagogy of on-line learning: A report from the University of the Highlands and Islands Millennium Institute

Siegel, E., see Mahon, B.

Simedy, W., see Hauer, M.

Smith, B., Preserving tomorrow's memory: Preserving digital content for future generations

Steenbakkers, J.F., Preserving electronic publications

(1) $19-26$

$(2,3) 49-50$

(4) $145-149$

$(2,3) 133-139$

$(2,3) \quad 89-96$

Wang, B., see Dong, E.

Welker, C.B., The paradigm of Viral Communication

(1) $27-31$

(1) $3-8$

Woodyard, D., Metadata and preservation 